\title{
ASSESSING THE FUTURE OF RURAL POLICING \\ The impact of closing the Commandos
}

Jonny Steinberg, criminal justice researcher

jsteinberg@ionaccess.co.za

Implicit in President M beki's controversial announcement in February 2003 that the Commandos are to be phased out is a statement that the SAPS is now strong enough to police rural South Africa on its own, and that the uncomfortable, transitional role the military has been playing in this area can come to an end. The key question posed in a recent ISS study was whether rural policing would be strengthened or weakened by the decision. The research suggests that closing the Commandos will weaken rural policing but strengthen the policing of contact crimes in rural towns.

$\mathrm{I}$ n February 2003, President Thabo M beki announced that the South African Defence Force's Territorial Reserve, popularly known as the Commandos, would be phased out. This phasing out process is now well underway. By the end of 2009, the last of South Africa's 183 Commandos will have ceased operating, their rural crime prevention and borderline control functions taken over by the South African Police Service (SAPS).

The announcement that the Commandos are to be phased out has elicited a great deal of controversy. This is hardly surprising. Any debate about the Commandos must inevitably find itself tackling the charged and difficult question of the relationship between security and race. At one end of the spectrum, government has been accused of leaving isolated white families of the agricultural hinterland vulnerable to violent crime. At the other, it has been lauded for closing down a quasi-private militia sensitive to white farmers' security but insensitive to black citizens' rights.

\section{Background to the Commandos}

The Commandos have in fact occupied an awkward and ambivalent position in government thinking ever since 1994. From the inception of the South African D efence Force in the 1960s, assisting the police with day-to-day policing was never meant to be a central function of the Commandos. The Commandos' primary function was then, and remains now, one of rear area defence during wartime. Rear area defence consists in securing military communication and supply lines, guarding strategic civilian infrastructure such as power stations, national key points such airports and broadcasting infrastructure, and protecting civilian life from enemy hostility in rural South Africa. The rationale is to free up permanent forces for frontline warfare.

The most prominent secondary function conceived for the Commandos was that of assisting state departments in times of crisis, be the crisis drought or floods, civil disorder, or the outbreak of an epidemic. Commandos' involvement in policing really escalated as a matter of circumstance - the circumstance being the internal insurgency against apartheid which began in June 1976 and never really ended until the demise of the old order. The policing with which Commandos were involved was blunt, aggressive and paramilitary. A veteran 
Commando member interviewed for this study in Johannesburg's West Rand recalled participating in an "internal security operation" in the township of Khutsong. He told us that:

We literally used to close the entire township down. Hundreds of soldiers and riot police would cordon off the whole township and we would search every room of every house and every shack in every street. The operation would take maybe four or five hours. By the end of it, we had between us seen every article of underwear in the township, every Sunday dress, every kitchen ladle.

It is hardly surprising that when the African National Congress came to power in 1994 it felt strongly that the role of the SANDF in ordinary policing should cease. The 1996 D efence W hite Paper made it clear that it was "a matter of urgency that plans are formulated to allow for the withdrawal of the SANDF from a policing role." ${ }^{1}$

Realities on the ground during the mid-1990s, however, mitigated against the removal of the Commandos from policing functions. While South Africa's new police force, the SAPS, was getting its house in order, the crime rate remained high. Crime in rural areas took on inflammatory political meanings. Violent crimes against farmers were dubbed 'farm attacks', a heavily loaded term which suggested a blurring of the lines between criminal aggression and guerrilla activity, and between acquisitiveness and political revenge.

Faced with high levels of violent crime which had been sharply politicised, and a police force distracted by the tasks of consolidation, the withdrawal of the crime fighting capacity from rural areas contained in the Commandos was deemed extremely unwise.

Thus, the Commandos occupied this ambivalent noman's-land role for the first ten years of democracy. President M beki's February 2003 announcement that the Commandos were to be phased out is an implicit statement that the SAPS is now strong enough to police rural South Africa on its own, that the uncomfortable, transitional role the military has been playing in the policing of rural South Africa can come to an end.

The task of a recent research project conducted for the Institute for Security Studies, the findings of which are summarised in this article, was to determine whether President $\mathrm{M}$ beki is right. O ur task was to assess the rural safety capacity that will be lost with the closing of the Commandos, and to discuss the manner in which the SAPS will replace that capacity. The ultimate question we posed was whether rural policing would be strengthened or weakened by the closure of the Commandos. ${ }^{2}$

\section{Composition and functions of the Commandos}

The early 1990s was a period of weakening and decline for the Commandos. They haemorrhaged personnel copiously, partly because of the end of conscription, partly because many veteran members refused to work for the military under an ANC government. They also began to suffer under steady and incremental budget cuts, as South Africa's military spending in general began to decline.

Beginning in 1996, the Territorial Reserve was given a budget to recruit aggressively in the black townships of rural South Africa. The vast majority of the new recruits were unemployed and joined in order to earn a living. Following a period of basic training, an entry level recruit earns R114.00 per day (in 2005 prices) and can work for up to 180 days per year. An entry level Territorial Reserve member can thus earn in the region of $\mathrm{R} 20,000$ per year, no mean sum in the context of a rural South African township.

As far as recruitment criteria are concerned, recruits must be South African citizens, must not have a criminal record, and should have a matric school qualification. However, a large number of recruits with a Standard Eight education have also been accepted into the Territorial Reserve over the last decade.

The Territorial Reserve thus changed dramatically in a very short space of time. In 1990, it was the institution into which hundreds of thousands of white South African men were periodically mobilised for military service. Its manifest presence was that of an 
auxiliary force in the maintenance of public order and social and political control. By 1996, it was a very different beast. White membership had dwindled considerably - in some areas to little as a few dozen. Black membership grew exponentially as the Territorial Reserve became a de facto employment provider and skills developer in rural towns across the country. At present, between 12,000 and 15,000 people are solely dependent on Commando work for their income. ${ }^{3}$

The Commandos of today bear the hallmarks of this legacy. Each Commando hosts two types of structures: area bound units and non-area bound units. Generally - although there are obviously many exceptions - white members of the Commando are full participants in the civilian economy and thus give comparatively little of their time to Commando work. They are generally active in area bound units. These units have two functions:

- gathering of information and intelligence, which gets relayed to joint, interdepartmental security planning structures; and

- an area bound rapid response capacity, in essence a mutual assistance function for neighbours, particularly rapid response in a time of emergency.

The demands on the time of a member of an area bound unit are small. To remain active and retain his entitlement to keep an army-issue assault rifle at his home, a member must report quarterly for weapons training and must submit to annual inspections which ensure that his weapon is properly stored and in good working order.

The second type of unit present in each Commando is the non-area bound unit, also known as the reaction unit. These are largely - again, not entirely - staffed by black members recruited in the mid and late 1990s. Most wish to maximise the amount of time they spend on duty, for they are breadwinners whose primary or sole source of income is Commando work.

Non-area bound units are not permitted to work independently of the police. They are strictly an auxiliary force, assisting in intelligence-driven crime prevention SAPS operations. They are, in short, a force multiplier, one with limited powers and capacities. Below is a list of the types of operations non-area bound units are permitted to join, and, where necessary, a brief description of their operation-specific role:

- observation posts (Commando members do not have powers of apprehension or arrest. O bservation posts should be led by SAPS members);

- listening posts;

- roadblocks (Commando members' function is to secure the roadblock; they do not have powers to search vehicles or to approach members of the public and they are also not permitted to open fire on vehicles which fail to stop at roadblocks);

- vehicle check points;

- vehicle and foot patrols (again, SANDF soldiers do not have powers of apprehension or arrest and patrols should be led by police officials);

- cordon-and-search operations (SANDF soldiers have the powers to cordon, but not to search).

To give a sense of the scale of the Commandos and the operations in which they are involved, at the end of $M$ arch 2004 total Commando strength was 43,976 , of which 17,957 was utilised and 26,019 was dormant. Between the beginning of April 2004 and the end of March 2005, Commando members were involved in 79,004 operations. The vast majority of these were farm visits $(29,351)$ and vehicle patrols $(24,242)$. Commando members were also present at more at 9,072 foot patrols, 4,207 roadblocks, 2,926 vehicle check points, 2,995 observation posts, 4,907 cordon-and-search operations, 16 air support operations, 46 motorcycle patrols and 49 equestrian patrols. ${ }^{4}$

As can be seen from the description of their functions above, the non-area bound units are pretty blunt policing instruments. Equipped with very restricted policing powers and highly circumscribed functions, they are little more than feet on the ground, or force multipliers. Their job is really that of a kind of security guard - defending the agricultural property - and increasing security force visibility in rural areas.

In our experience, though, SAPS station commissioners were delighted, in some cases 
relieved, to have them. The typical rural policing jurisdiction in South Africa includes a rural town at its centre - replete with suburbs, townships, and informal settlements - and a vast expanse of farmland stretching to its periphery.

The vast majority of reported crimes - from burglary, to robbery, to assault - occur in town centres, and that is where station commissioners invest the greater part of their personnel and infrastructure. Station commissioners are thus only too delighted to have a steady and reliable source of force multipliers to assist in the policing of the rural districts of their jurisdictions. Indeed, in two of the three areas we visited, farmers had come to rely far more on the Commandos than police for their primary policing services.

\section{Do Commandos represent rural SA?}

Although the research suggests that Commandos do not represent the rural population of the country, this finding is less controversial than may appear at first sight.

Typical Commando operations are aimed at preventing crimes against the people, property and businesses of the rural middle class. D oes this make the Commando a problematic structure? Political orthodoxy tells us that all public security structures must represent everybody's interests, that the Commandos, for instance, must include everybody. But is that goal possible?

Rural South African communities are deeply divided - by race, by inequality, and by a great deal of history. Asking a public security structure - whether a Commando or the SAPS - to bridge these divides, is perhaps asking too much. It is asking a structure tasked with defending people and property to mend souls; a structure with limited means and blunt instruments to conduct social engineering. Public security organs must, of course, be given mandates which are fair. And everybody must be given the policing service they require. But that is a very different point.

However, when the capacity contained in the Commandos is used injudiciously, they can indeed cause a great deal of harm. When every gathering of black people around a crate of beer is deemed to be a hotspot; when every rural drinking establishment in the countryside is deemed a potential source of crime; when every rural settlement is regarded as a hideout for criminals, Commandos begin to aggravate racial tensions and to do their jobs inequitably. That is when they begin to police the property of one constituency by invading the privacy and violating the dignity of another.

Commandos ought to do 'hotspot policing' - putting uniformed bodies in places where crime is know $n$ to occur. But the sort of hotspot policing at which they are best is largely passive. Their job is not to scour the countryside for weapons and potential criminals.

\section{Rural policing without the Commandos}

Despite many hiccups, at the time of writing it appears that the SAPS will successfully replace the capacity that will be lost with the closure of the Commandos. The SAPS has set aside a budget to recruit and remunerate an annually escalating number of reservists beginning in the current financial year until 2009. Many of these reservists will hopefully be recruited directly from the ranks of the Commandos.

For the 2005/06 financial year, funds have been set aside to call up 2,000 reservists for a maximum of seven days per month for active duty. This figure will rise incrementally until by 2009/10 20,000 reservists will be called up for a maximum of seven days per month. At the rank of Inspector, reservists will be paid R126.99 per day of active duty at 2005 prices. $^{5}$

If one assumes that 12,000 part-time soldiers currently earn a living in the Commandos, and that they work an average of 120 days per year, their collective manpower totals 1.44 million working days per year. If, by 2009 , the SAPS deploys 20,000 reservists on active duty for seven days each month, collective manpower will total 1.68 million working days per year.

By this narrow and limited measure, a total gain of $14 \%$ of annual working days would have been achieved by the time the last Commando closes its doors in $2009 .{ }^{6}$ The issue that remains is how the SAPS will fashion and deploy this capacity. 


\section{Rural towns vs, the agricultural hinterland}

It is our contention that the SAPS will, over time, shift increasing proportions of the capacity it inherits from the Commandos from the rural districts and into the town centres of rural policing jurisdictions. The closure of the Commandos will thus result in the weakening of rural policing but in the strengthening of the policing of contact crimes in rural town centres.

All police services exercise discretion in deciding which aspects of policing to prioritise. In the SAPS, this discretion is exercised primarily at a national level. Area and station level managers are given quantifiable crime reduction and police action targets to meet. At present, the highest priority crimes in the SAPS are contact crimes, and are attached to an annual crime reduction target of seven percent. This is a normative, value-laden decision, and a commendable one at that.

In small town police stations, however, the policing of rural sectors will suffer as a result. Many of these stations straddle a sharp divide between urban and rural areas. Most contact crimes are committed in urban sectors. If and when the capacity contained in the Commandos is transferred to the police, area and station level managers are bound to transfer much of this capacity from the rural sectors in which it is now deployed to urban sectors. Not to do so would be to respond irrationally to their own performance indicators; they must do so in an attempt to meet their targets.

In making this argument, we are not necessarily criticising the police. We acknowledge that deciding how to distribute policing resources is a difficult matter and that the decisions the SAPS has made in this regard are entirely defendable. Prioritising the policing of, say, aggravated robbery over sheep theft is not just understandable but commendable. The SAPS should be aware though that there are places where its existing organisational incentives might, unless checked, result in situations where agricultural crimes are almost entirely unpoliced.

The SAPS should also consider that the station commissioners who inherit the capacity currently contained in the Commandos will be placed in an invidious position. On the one hand, a very vocal and vociferous local constituency - commercial farmers - will protest that existing capacity be left where it is at very least; strengthened at best. They will demand better service.

Indeed, by establishing Crime Sector Forums in rural sectors, the SAPS is encouraging that such demands be made. Yet pressure exerted on the station commissioner from within the SAPS, in the form of performance targets, will be to feed the urban sectors at the price of rural sectors. The station commissioner will find himself wedged between the demands of a grassroots constituency and the priorities established nationally.

\section{Acknowledgement}

This article is based on a monograph published recently by the Institute for Security Studies: J Steinberg, After the Commandos: the future of rural policing in South Africa, ISS M onograph 120 , Oct 2005.

\section{Endnotes}

1 South African White Paper on Defence, Chapter 4, paragraph 33, 1996, at <http://www.mil.za/Articles\& Papers/Frame/Frame.htm>.

2 After their closure, the Commandos' non-policing functions - namely, wartime rear area defence and peacetime assistance in "exceptional circumstances" will become the responsibility of the permanent force. Assessing the SANDF's capacity to perform these functions after the closure of the Commandos was beyond the remit of our research.

3 Author's correspondence with Major General JF Lusse, co-chairman, National Joints Task Team, 2 August 2005.

4 Ibid.

5 Author's communication with SAPS Assistant Commissioner Ben Groenewald, 26 July 2005.

6 Individual Commando members who are recruited into the police reserve will not, however, gain a $14 \%$ increase in income. On the contrary, they will lose income. Currently, an entry-level recruit in the Commandos (the equivalent to a police corporal) who works 120 days per year at R144 per day earns R13,680 per year. Under the police reserve dispensation, a middle-ranking inspector, working his maximum of 84 days per year, will earn R10,667 per annum. Commando members who join the police reserve, and rely solely on their SAPS work for their livelihoods, will in general experience a steep decline in income. 